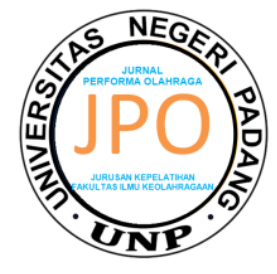

Jurnal Performa Olahraga

ISSN Online : 2714-660X ISSN Cetak : 2528-6102

Journal Homepage : http://performa.ppj.unp.ac.id/index.php/kepel

Volume 6 Nomor 1, 2021, Hlm 43-52

DOI: https://doi.org/10.24036/ipo235019

\title{
PENGARUH KADAR HEMOGLOBIN DAN KEBUGARAN JASMANI TERHADAP HASIL BELAJAR PENDIDIKAN JASMANI OLAHRAGA DAN KESEHATAN (PENJASORKES)
}

\author{
Agung cahyadi ${ }^{1}$, Rizkei Kurniawan ${ }^{2}$ \\ ${ }^{1}$ Pendidikan Jasmani,Fakultas Keguruan dan Ilmu Pendidikan, Universitas Islam \\ Kebangsaan Indonesia, Indonesia \\ 2Pendidikan Jasmani, Fakultas Keguruan dan Ilmu Pendidikan, Universitas Samudra, \\ Indonesia
}

Informasi Artikel

Diterima 2021-02-05

Direvisi 2021-06-21

Dipublikasikan 2021-08-31

\section{Keyword:}

Hemoglobin Level

Physical Fitness

Learning Outcomes in Physical

Education, Sport and Health

Course

\begin{abstract}
This study was based on the problem found among the students of SMAN 2 Padang related to the low learning outcomes in Physical Education, sport and health course. These learning outcomes were affected by hemoglobin levels and physical fitness. This study aims to identify the direct and indirect effects among the variables hemoglobin levels, and physical fitness towards learning outcomes in Physical Education, sport and health course.Quantitative research method with Path Analysis approach was carried out in this study. The study involved 308 (all) male students of SMAN 2 Padang in academic year 2018-2019 as the population. 100 students were taken as the sample by using Proportional Stratified Random Sampling. The data were collected using $\mathrm{Hb}$ test meter for hemoglobin levels; physical fitness test for physcal fitness; and the first semester exam results for learning outcomes. The results of data analysis show that the learning outcomes in Physical Education, sport and health course were: (1) affected directly by hemoglobin levels for 5.34\%, (2) physical fitness for 13.40\%; (2) affected indirectly by hemoglobin levels and physical fitness for $12.9 \%$,
\end{abstract}

(c) 2020 The Authors. Published by Universitas Negeri Padang. This is an open access article under the CC BY-NC-SA license (https://creativecommons.org/licenses/by-nc-sa/4.0/

\section{Penulis Korespondensi:}

Nama Penulis, Agung cahyadi

Lembaga, Universitas Islam Kebangsaan Indonesia

Email: agungcahyadi0506@gmail.com

\section{PENDAHULUAN}

Pendidikan adalah usaha sadar yang dilakukan oleh keluarga, masyarakat dan pemerintah melalui kegiatan bimbingan, pengajaran dan latihan yang berlangsung di sekolah dan di luar sekolah untuk mempersiapkan peserta didik agar mampu mengembangkan pengetahuan, keterampilan dan kreatifitas. Seorang peserta didik dapat dikatakan berhasil dalam belajar apabila terjadi perubahan tingkah laku di dalam dirinya, baik dalam bentuk pengetahuan, keterampilan maupun dalam bentuk sikap dan nilai positif. Suryabrata (2012:232) menjelaskan bahwa belajar membawa pada perubahan yang meliputi: (a) perubahan baik aktual maupun potensial, (b) perubahan itu pada pokoknya menghasilkan kecakapan baru, dan (c) perubahan itu terjadi karena 
usaha yang disengaja. Berdasarkan pendapat tersebut, dapat disimpulkan bahwa belajar adalah suatu proses perubahan yang tidak tau menjadi tau yang tidak mengerti menjadi mengerti, Orang yang belajar makin lama dapat mengerti akan adanya hubungan dan perbedaan bahan yang dipelajari. Pada dasarnya tujuan belajar adalah ingin mendapatkan pengetahuan dan keterampilan.

Tujuan belajar merupakan kriteria untuk menilai derajat mutu dan efisiensi pembelajaran. Hamalik (2009:73) mengatakan bahwa "tujuan belajar adalah sejumlah hasil belajar yang menunjukkan bahwa siswa telah melakukan perbuatan belajar, yang umumnya meliputi pengetahuan, keterampilan dan sikap-sikap yang baru, yang diharapkan tercapai oleh siswa". Itu sebabnya, setiap guru perlu memahami dengan seksama tujuan belajar dan pembelajaran sebagai bagian integral dari suatu sistem pembelajaran. Sebagaimana dikemukan oleh UNESCO dalam Ruhimat, dkk (2011:140) ada empat pilar hasil belajar yang di harapkan dapat dicapai oleh pendidikan, yaitu: lerning to know, lerning to be, learning to life together, dan learning to do. Selanjutnya, Sudjana (2011:45) melihat belajar melalui tiga sudut pandang yaitu, melihat belajar sebagai proses, melihat belajar sebagai suatu hasil, dan melihat belajar sebagai suatu fungsi. Sedangkan Gagne dalam Dahar (2011:118) mengemukakan lima macam hasil belajar, tiga diantaranya bersifat kognitif, satu bersifat afektif dan satu lagi bersifat psikomotorik.

Begitu juga halnya dengan hasil belajar penjasorkes yang bertujuan adanya perubahan sikap dan tingkah laku apakah itu dalam bentuk pengetahuan dan keterampilan maupun sikap yang terjadi dalam diri peserta didik.Susanto (2013:12-13) menjelaskan bahwa Faktor-faktor yang mempengaruhi hasil belajar adalah Faktor internal dan factor eksternal. faktor internal merupakan faktor yang bersumber dari dalam diri peserta didik, yang mempengaruhi kemampuan belajarnya. Faktor intenal ini meliputi kecerdasan, minat dan perhatian, motivasi belajar, ketekunan, sikap, kebiasaan belajar, serta kondisi fisik dan kesehatan. Dan faktor eksternal adalah faktor yang berasal dari luar diri peserta didik yang mempengaruhi hasil belajar yaitu keluarga, sekolah dan masyarakat dan sebagainya, Dari pendapat diatas dapat disimpulkan bahwa hasil belajar siswa dipengaruhi oleh banyak faktor, diantaranya kesehatan salah satunya kadar hemoglobin, motivasi (intrinsik dan ekstrinsik),kebugaran jasmani, status gizi, minat belajar, ekonomi, dukungan orang tua, guru dan lain sebagainya

(Hapzah dkk, 2012:55)Salah satu kelompok yang rentan menderita anemia adalah anak sekolah, karena pada anak usia sekolah berada dalam masa pertumbuhan yang membutuhkan zat gizi yang tinggi dan status gizi baik sehingga peserta didik yang memiliki status gizi yang baik akan terlihat lebih bersemangat dan tidak loyo disaat pembelajaran sedang berlangsung. Kadar hemoglobin adalah ukuran pigmen respiratorik dalam butiran butiran darah merah. Jumlah hemoglobin dalam darah normal adalah kira kira $15 \mathrm{gr}$ setiap $100 \mathrm{ml}$ darah dan jumlah ini disebut "100 persen"(Evelyn dalam Dwi aries 2015:35)Batas normal nilai hemoglobin untuk seseorang sukar ditentukan karena kadar hemoglobin bervariasi di antara setiap suku bangsa. Selain itu kadar hemoglobin juga dipengaruhi oleh berbagai macam faktor lain, di antaranya adalah usia, jenis kelamin,asupan zat besi (status gizi),keadaan demografis (pantai dan gunung), gaya hidup (minuman alkohol, kafein),pola makan serta penyakit kronis (malaria, infeksi cacing tambang, TBC dll). Menurut Slone,(2005:71) Fungsi hemoglobin adalah (a)Mengatur pertukaran oksigen dengan karbondioksida didalam jaringan tubuh (b)Mengangkut oksigen dari paru-paru kemudian dibawa keseluruh jaringan tubuh untuk dipakai sebagai bahan bakar (c)Mengatur Ph darah, buffer asam basa

Latihan dan aktivitas fisik manusia sangat mempengaruhi kadar hemoglobin dalam darah. Pada individu yang secara rutin berolahraga kadar hemoglobinnya akan sedikit naik. Hal ini disebabkan karena jaringan atau sel akan lebih banyak membutuhkan 02 (oksigen) ketika melakukan aktivitas (Bahri dkk dalam Mirza Juanda (2013).

Aktivitas fisik yang dilakukan manusia akan berpengaruh terhadap peningkatan atau penurunan kadar hemoglobin dalam darah.( Sadikin M, 2002). Aktivitas fisik terbagi atas aktivitas fisik ringan, aktivitas fisik sedang dan aktivitas fisik berat. (Chan TH, 2016. Aktivitas fisik yang dapat mempengaruhi kadar $\mathrm{Hb}$ ialah aktivitas fisik intensitas sedang hingga berat(Santoso G, 2004. Perubahan kadar Hb melalui aktivitas fisik sedang sampai berat, dihipotesiskan terjadi karena perubahan volume plasma, perubahan $\mathrm{pH}$, dan hemolisis 
intravaskular. (Mairbaurl H, 2013)

Saat melakukan aktivitas fisik seperti berolahraga akan terjadi peningkatan aktivitas metabolik yang tinggi, asam yang diproduksi berupa ion hidrogen dan asam laktat akan semakin banyak, hal ini akan menyebabkan terjadinya penurunan $\mathrm{pH}$. Afinitas antara oksigen dan hemoglobin akan menurun apabila $\mathrm{pH}$ darah rendah. Apabila afinitas tarik antara oksigen dan hemoglobin menurun, maka hemoglobin akan melepaskan lebih banyak oksigen sehingga meningkatkan pengiriman oksigen ke otot (Kosasi L, Oenzil F, Yanis A 2014;3). Latihan dan aktivitas fisik manusia sangat mempengaruhi kadar hemoglobin dalam darah. Pada individu yang secara rutin berolahraga kadar hemoglobinnya akan sedikit naik. Hal ini disebabkan karena jaringan atau sel akan lebih banyak membutuhkan 02 (oksigen) ketika melakukan aktivitas (Bahri dkk dalam Mirza Juanda (2013).

Menurut Corbin dkk (dalam chen dkk 2014) "Health-related physical fitness refers to our body's ability to function efficiently and effectively and is an important indicator of health". Pendapat tersebut mengatakan kesehatan berhubungan dengan kebugaran fisik mengacu pada kemampuan tubuh kita untuk berfungsi secara efisien dan efektif dan merupakan indikator penting dari kesehatan. Menurut T Cholick Muthoir dalam ismaryati(2008:40)"kebugaran jasmani merupakan kondisi yang mencerminkan kemampuan seseorang untuk melakukan tugas dengan produktif tanpa mengalami kelelahan yang berarti. Sebagai bagian dari program pendidikan jasmani di sekolah, pembinaan kebugaran jasmani sangat strategis, karena mendukung kapasitas belajar bagi siswa dan menggiatkan partisipasi siswa secara menyeluruh. Selanjutnya menurut Ortega, dkk (dalam Piccinno \& Collela 2014:50) kebugaran jasmani merupakan indeks terbaik dari kondisi kesehatan pada usia berapa pun.

Menurut Wiarto (2013:169-170) ada beberapa faktor yang mempengaruhi tingkat kebugaran jasmani seseorang, (1) usia, (2) jenis kelamin, anak laki-laki setelah pubertas mempunyai tingkat kebugaran jasmani jauh lebih besar dari perempuan. (3) genetik, (4) makanan, daya tahan yang tinggi bila mengkonsumsi tinggi karbohidrat (60-70\%). Diet tinggi protein terutama untuk memperbesar otot dan untuk olahraga yang memerlukan kekuatan otot yang besar. (5) rokok, kadar zat-zat di dalam rokok akan mengurangi nilai VO2 maks, yang berpengaruh terhadap daya tahan.

Secara umum menurut Boucharrd dalam Apri Agus (2012:29), komponen kebugaran jasmani atau unsur-unsur yang terdapat kebugaran jasmani itu ada yang berkaitan dengan nilainilai kesehatan dan kemampuan motorik.

Kebugaran jasmani yang bekaitan dengan nilai-nilai kesehatan meliputi: (a) daya tahan jantung (cardiovasculer), (b) kekuatan otot (strenght), (c) daya tahan otot (ketahanan muskculator), (d) kelentukan (flexibelity), (e) Komponen tubuh.

Sedangkan kebugaran jasmani yang berhubungan dengan nilai-niai keterampilan motorik, meliputi: (a) Keincahan (agility, (b) kecepatatan (speed), (c) keseimbangan (balance), (d) koordinasi (coodination), (e) Daya ledak (power)

permasalahan ini diduga disebabkan oleh faktor-faktor yang mempengaruhi hasil belajar peserta didik yaitunya faktor intrinsik kesehatan (kadar hemoglobin), status gizi, bakat, minat, motivasi, tingkat kebugaran jasmani) dan juga faktor ekstrinsik (sarana dan prasarana, kompetensi guru, letak geografis sekolah, ekonomi keluarga, pendidikan orang tua, lingkungan masyarakat dan lingkungan sekolah). Kadar hemoglobin, status gizi, bakat, minat, motivasi dan tingkat kebugaran jasmani setiap peserta didik berbeda. Ada yang memiliki kadar hemoglobin yang rendah, sehingga berpengaruh pada perkembangan mental, dan perkembangan psikomotor, sehingga prestasi belajarnya lebih rendah dibandingkan dengan anak normal

\section{METODE}

Berdasarkan permasalahan dan tujuan penelitian, maka metode yang digunakan dalam penelitian ini adalah metode kuantitatif dengan menggunakan pendekatan Path Analysis yaitu 
menggunakan persamaan struktural yang melihat kaualitas dimensi pengaruh Kadar Hemoglobin $\left(\mathrm{X}_{1}\right)$ dan Kebugaran Jasmani $\left(\mathrm{X}_{2}\right)$ terhadap Hasil Belajar Penjasorkes $(\mathrm{Y})$

Menurut Riduwan (2011:115) Analisis jalur merupakan sarana atau teknik yang dapat membantu peneliti untuk menjelaskan proses yang bersifat kausal data kuantitatif korelasional. Menurut Kadir (2015:239) analisis jalur adalah teknik analisis yang digunakan untuk mempelajari hubungan kausal antara variabel bebas dan variabel terikat dimana hubungan kausal ini disusun dalam bentuk model hipotetitk yang didasarkan pada subtansi keilmuan yaitu landasan teori. Menurut Riduwan dan Kuncoro (2011:2) bahwa analisis jalur digunakan untuk menganalisis pola hubungan antar variabel dengan tujuan untuk mengetahui pengaruh langsung maupun tidak langsung seperangkat variabel bebas (independen) terhadap variabel terikat (dependen). Konsep penelitian ini membuktikan terdapat atau tidak terdapat pengaruh variabel penyebab (eksogen) terhadap variabel terikat (endogen) dengan menggunakan metode Path Analysis, Penelitian ini dilakukan di SMAN 2 Kota Padang, sedangkan waktu penelitian dilaksanakan pada bulan Juni 2019.

Populasi penelitian ini adalah seluruh siswa putra kelas X dan XI SMAN 2 Kota Padang yang berjumlah 308 orang, menurut Yusuf (2013:146) "populasi merupakan totalitas semua nilainilai yang mungkin dari pada karakteristik tertentu sejumlah objek yang ingin dipelajari sifatsifatnya". Pengambilan sampel dilakukan dengan menggunakan Teknik "Proportional Stratified Random Sampling". menurut Arikunto (2010:174) "sampel dalam penelitian adalah sebagian atau wakil populasi yang diteliti". Untuk menentukan ukuran sampel dari populasi digunakan pendekatan Slovin, total peserta didik yang terpilih menjadi sampel adalah sebanyak 100 orang.

Variabel dalam penelitian ini adalah kadar hemoglobin,kebugaran jasmani dan hasil belajar penjasorkes siswa putra SMA Negeri 2 Kota Padang. Data variabel kadar hemoglobin diperoleh dari hasil pemeriksaan sampel darah menggunakan Hb meter, variabel kebugaran jasmani menggunakan Tes Kebugaran Jasmani Indonesia (TKJI) untuk putra usia 16-19 tahun, serta variabel hasil belajar diperoleh dari nilai rapor penjasorkes

\section{HASIL DAN PEMBAHASAN}

\section{Hasil Penelitian}

\section{Kadar Hemoglobin}

Tabel 1. Distribusi Frekuensi Data Kadar Hemoglobin

\begin{tabular}{|c|c|c|}
\hline Kelas Interval & Frekuensi Absolut & Frekuensi Relatif (\%) \\
\hline $9.6-11.5$ & 4 & 4 \\
\hline $11.6-13.5$ & 3 & 3 \\
\hline $13.6-15.5$ & 31 & 31 \\
\hline $15.6-17.5$ & 39 & 39 \\
\hline $17.6-19.5$ & 23 & 23 \\
\hline$\Sigma$ & 100 & 100 \\
\hline
\end{tabular}

Untuk lebih jelasnya dapat digambarkan sebagai berikut ;

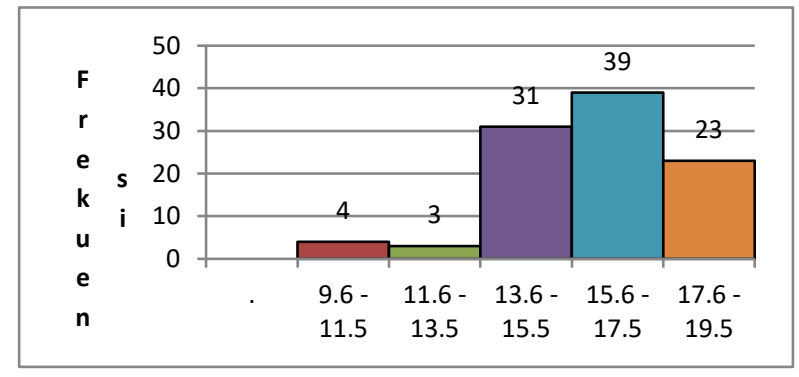




\section{Gambar 1. Histogram Data Kadar Hemoglobin}

Berdasarkan tabel dan histogram di atas terlihat kadar hemoglobin dari 100 orang sampel pada siswa putra SMA Negeri 2 Kota Padang sebanyak 4 orang responden berada dalam kelas interval 9.6-11.5, 3 orang responden berada dalam interval 11.6-13.5, 31 orang responden berada dalam interval 13.6-15.5, 39 orang responden berada dalam interval 15.6-17.5 dan 23 orang responden berada dalam interval 17.6-19.5.

\section{Kebugaran Jasmani}

Tabel 2. Distribusi Frekuensi Data Kebugaran Jasmani

\begin{tabular}{|c|c|c|}
\hline Kelas Interval & Frekuensi Absolut & Frekuensi Relatif (\%) \\
\hline $8-10$ & 6 & 6 \\
\hline $11-13$ & 22 & 22 \\
\hline $14-16$ & 49 & 49 \\
\hline $17-19$ & 21 & 21 \\
\hline $20-22$ & 2 & 2 \\
\hline$\sum$ & 100 & 100 \\
\hline
\end{tabular}

Untuk lebih jelasnya dapat digambarkan sebagai berikut ;

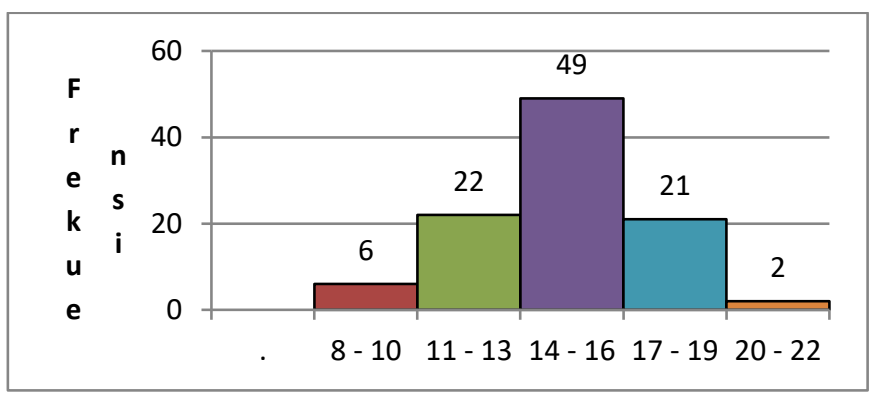

\section{Gambar 2. Histogram Data Kebugaran Jasmani}

Berdasarkan tabel dan histogram di atas terlihat kebugaran jasmani dari 100 orang sampel siswa putra SMA N 2 Kota Padang sebanyak 6 orang responden berada dalam kelas interval 8-10, 22 orang responden berada dalam interval 11-13, 49 orang responden berada dalam interval 1416, 21 orang responden berada dalam interval 17-19 dan 2 orang responden berada dalam interval 20-22.

\section{Hasil Belajar}

Tabel 3.Distribusi Frekuensi Data Hasil Belajar

\begin{tabular}{|c|c|c|}
\hline Kelas Interval & Frekuensi Absolut & Frekuensi Relatif (\%) \\
\hline $65-70$ & 16 & 16 \\
\hline $71-76$ & 11 & 11 \\
\hline $77-82$ & 33 & 33 \\
\hline $83-88$ & 30 & 30 \\
\hline $89-94$ & 10 & 10 \\
\hline$\sum$ & 100 & 100 \\
\hline
\end{tabular}


Untuk lebih jelasnya dapat digambarkan sebagai berikut ;

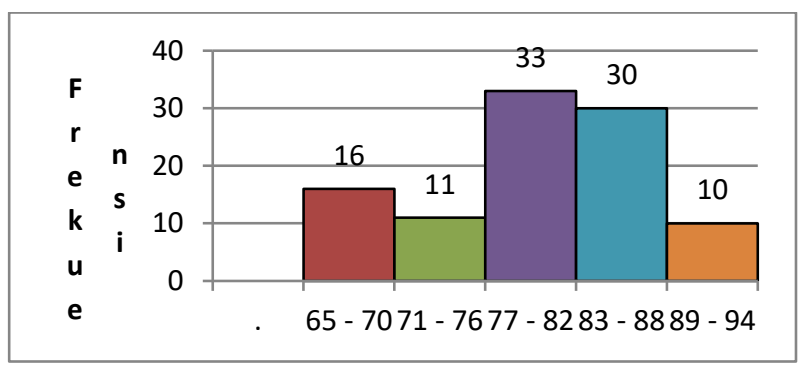

\section{Gambar 3. Histogram Data Hasil Belajar}

Berdasarkan tabel dan histogram di atas terlihat hasil belajar penjasorkes dari 100 orang sampel siswa putra SMA N 2 Kota Padang sebanyak 16 orang responden berada dalam kelas interval 65-79, 11 orang responden berada dalam interval 71-76, 33 orang responden berada dalam interval 77-82, 30 orang responden berada dalam interval 83-88 dan 10 orang responden berada dalam interval 89-94.

\section{Pembahasan}

1. Pengaruh langsung kadar hemoglobin terhadap hasil belajar penjasorkes siswa putra SMA Negeri 2 Kota Padang.

Berdasarkan penelitian yang telah peneliti laksanakan di lapangan ditemukan pengaruh langsung kadar hemoglobin $\left(\mathrm{X}_{1}\right)$ terhadap hasil belajar penjasorkes $(\mathrm{Y})$ siswa putra SMA Negeri 2 Kota Padang. individual yang dilakukan $\mathrm{X}_{1}$ terhadap $\mathrm{Y}$ didapatkan bahwa hasil koefesien jalur $\rho_{\mathrm{yx} 1}=0.231$ dengan nilai signifikansi $(\mathrm{sig})=0.012$ yang lebih kecil dari nilai probabilitas $(\alpha)=0,05$. Jadi dapat disimpulkan bahwa terdapat pengaruh langsung kadar hemoglobin terhadap hasil belajar penjasorkes siswa putra SMA Negeri 2 Kota Padang.

Hasil penelitian ini menunjukan bahwa kadar hemoglobin siswa putra SMA Negeri 2 Kota Padang ikut mempengaruhi hasil belajar penjasorkes yang mereka capai.kadar hemoglobin juga memberikan pengaruh secara signifikan yang ditunjukan dengan nilai 0,012 dimana nilai ini jelas lebih kecil dari pada nilai $\alpha=0,05$. Selain itu juga ditunjukan hubungan antara kadar hemoglobin dan hasil belajar penjasorkes siswa putra SMA Negeri 2 Kota padang yaitu dengan nilai $r=0.325$ atau $10.56 \%$.

Kadar hemoglobin adalah ukuran pigmen respiratorik dalam butiran-butiran darah merah. Ukuran kadar hemoglobin tergantung usia dan jenis kelamin. Ketika kondisi hemoglobin seseorang lebih tinggi atau rendah dari pada jumlah normal, dapat menjadi tanda adanya gangguan kesehatan. Kadar hemoglobin rendah berarti ada sesuatu pada tubuh seseorang seperti kekurangan nutrisi, kehabisan darah karena operasi, anemia atau kelainan darah, memiliki masalah dengan ginjal atau paparan radiasi. Sedangkan apabila kadar hemoglobin tinggi juga menunjukkan bahwa ada kelainan pada tubuh. Misalnya kemungkinan mengidap gangguan sumsum tulang, penggunaan obat yang tidak tepat, kanker, penyakit paru atau kebiasaan merokok.

Besar dampak yang ditimbulkan oleh anemia defisiensi besi seperti penurunan daya pikir dan konsentrasi, penurunan prestasi, kecerdasan intelektual, dan kebugaran dan kesehatan tubuh. Anak yang menderita anemia akibat defisiensi zat besi mempunyai nilai lebih uji kecerdasan intelektual dan kemampuan belajar yang rendah. (Triasih S.2005) Selain hal tersebut ada juga faktor lingkungan, seperti tinggal di daerah dataran tinggi menjadikan kadar hemoglobin menjadi tinggi juga.

Kondisi hemoglobin tinggi biasanya terjadi akibat reaksi tubuh saat kadar oksigen turun. Sehigga tubuh berusaha memasok oksigen lewat hemoglobin. Hemoglobin adalah protein dalam sel darah merah yang juga berisi zat besi. Hemoglobin ini berfungsi untuk mengangkut 
oksigen ke seluruh tubuh terutama paru-paru. Jadi fungsi hemoglobin sangat penting untuk tubuh.

Oleh karena itu seorang siswa yang tugas utamanya belajar, tentunya memiliki aktivitas fisik yang banyak, sebaiknya memilki kadar hemoglobin yang baik. Hal ini diartikan bahwa seseorang yang memilki aktivitas fisik tergolong aktif seperti saat melakukan latihan olahraga, diharapkan memiliki kadar hemoglobin sedikit lebih tinggi. Karena pada saat itu kebutuhan tubuh akan sumber energi meningkat terutama oksigen.

Dari hasil diatas, jelaslah bahwa kadar hemoglobin merupakan sebagai zat yang penting dalam tubuh untuk pertumbuhan dan menghasilkan energi untuk melakukan kerja fisik. Sedangkan dalam pembelajaran pendidikan jasmani olahraga dan kesehatan juga menuntut adanya kerja fisik. Sebagaimana dibuktikan dari hasil penelitian bahwa terdapat pengaruh signifikan kadar hemoglobin terhadap hasil belajar penjasorkes. Dengan demikian dapat di katakan siswa yang memiliki kadar hemoglobin yang baik, maka akan mempengaruhi kapasitas kebugaran jasmani, dalam hal ini memiliki tingkat kebugaran jasmani yang baik sehingga akan memperoleh hasil belajar penjasorkes yang baik juga.

2. Pengaruh langsung kebugaran jasmani terhadap hasil belajar penjasorkes siswa putra SMA Negeri 2 Kota Padang.

Berdasarkan penelitian yang telah peneliti laksanakan di lapangan ditemukan pengaruh langsung kebugaran jasmani $\left(\mathrm{X}_{2}\right)$ terhadap hasil belajar penjasorkes $(\mathrm{Y})$ siswa putra SMA Negeri 2 Kota Padang. individual yang dilakukan $\mathrm{X}_{2}$ terhadap $\mathrm{Y}$ didapatkan bahwa hasil koefesien jalur $\rho_{\mathrm{yx} 2}=0.366$ dengan nilai signifikansi $(\mathrm{sig})=0,000$ yang lebih kecil dari nilai probabilitas $(\alpha)=0,05$. Jadi dapat disimpulkan bahwa terdapat pengaruh langsung kebugaran jasmani terhadap hasil belajar penjasorkes siswa putra SMA Negeri 2 Kota Padang.

Hasil penelitian ini menunjukan bahwa kebugaran jasmani siswa putra SMA Negeri 2 Kota Padang ikut mempengaruhi hasil belajar penjasorkes yang mereka capai. selain memberikan pengaruh yang langsung kebugaran jasmani juga memberikan pengaruh secara signifikan yang ditunjukan dengan nilai 0,000 dimana nilai ini jelas lebih kecil dari pada nilai $\alpha=0,05$. Selain itu juga ditunjukan hubungan antara kebugaran jasmani dan hasil belajar penjasorkes siswa putra SMA Negeri 2 Kota Padang yaitu dengan nilai $r=0.339$ atau $11.49 \%$.

Menurut Corbin dkk (dalam chen dkk 2014) "Health-related physical fitness refers to our body's ability to function efficiently and effectively and is an important indicator of health". Pendapat tersebut mengatakan kesehatan berhubungan dengan kebugaran fisik mengacu pada kemampuan tubuh kita untuk berfungsi secara efisien dan efektif dan merupakan indikator penting dari kesehatan.

Chomitz (2009) mengatakan terdapat hubungan yang signifikan antara kebugaran dengan prestasi akademik pada siswa sekolah umum di Amerika Serikat. Kegiatan olahraga juga memperbaiki fungsi-fungsi penting, kemampuan berkonsentrasi, ingatan, dan intelektual (Tomporiski et al., 2008). Kegiatan olahraga juga menstimulasi bagian otak dan menyebabkan keluarnya BDNF (Brain Derived Neurotropic Factor) yang berpengaruh terhadap ketajaman berpikir, peningkatan memori,fokus, dan konsentrasi.

Dari pendapat di atas dapat dikatakan bahwa kebugaran jasmani adalah kemampuan tubuh seseorang untuk melakukan tugas dalam kehidupan sehari-hari, Dengan kata lain bahwa kebugaran jasmani merupakan cerminan dari kemampuan fungsi sistem-sistem dalam tubuh yang dapat mewujudkan suatu peningkatan kualitas hidup dalam setiap aktivitas. Kebugaran jasmani sangat menentukan keberhasilan siswa dalam mencapai hasil belajar yang maksimal. Siswa yang mempunyai kebugaran jasmani yang tinggi akan tercermin pada dirinya saat mengikuti pembelajaran. Siwa akan mampu mengikuti pembelajaran Penjasorkes 
dengan tanpa kelelahan serta masih mampu melakukan aktivitas setelah pemebelajarn Penjasorkes. Kebugaran jasmani tidak tercipta dengan waktu yang singkat, tapi dibutuhkan waktu yang lama agar tubuh mempunyai kondisi yang tidak mudah lelah dalam beraktivitas

Kebugaran jasmani merupakan salah satu faktor penunjang keberhasilan siswa yang dinilai dari hasil belajar. Meskipun pada kenyataan dilapangan ada kalanya siswa yang mempunyai kebugaran jasmani baik, belum tentu diikuti dengan hasil belajar yang baik pula, begitu juga sebaliknya rendahnya hasil belajar belum tentu juga dikarenakan rendahnya tingkat kesegaran jasmani.

Mencermati hal ini, kita ketahui juga bahwa kebugaran jasmani tidak hanya menuntut keadaan kondisi secara fisikalis saja, tetapi juga menuntut keterlibatan seluruh aspek tubuh seseorang, diantaranya kemampuan berpikir (kecerdasan) yang dimiliki. Artinya bahwa kebugaran jasmani merupakan suatu kemampuan yang dapat mempengaruhi tingkat kecerdasan berpikir seseorang. Artinya kedua elemen yang dimaksud saling memberikan pengaruh yang bermakna. Akhirnya didasarkan pada pembuktian uji statistik di atas, disimpulkan bahwa komponen kebugaran jasmani berpengaruh terhadap hasil belajar siswa, khususnya siswa putra SMA Negeri 2 Kota Padang.

3. Pengaruh kadar hemoglobin melalui kebugaran jasmani terhadap hasil belajar penjasorkes siswa putra SMA Negeri 2 Kota Padang.

Berdasarkan penelitian yang telah peneliti laksanakan di lapangan terhadap kadar hemoglobin, kebugaran jasmani dan hasil belajar penjasorkes siswa putra SMA Negeri 2 Kota Padang ditemukan bahwa terdapat pengaruh tidak langsung kadar hemoglobin $\left(\mathrm{X}_{1}\right)$ terhadap hasil belajar penjasorkes $(\mathrm{Y})$ melalui kebugaran jasmani $\left(\mathrm{X}_{2}\right)$ sebesar 0.359 sehingga $\mathrm{H}_{\mathrm{o}}$ ditolak dan $\mathrm{H}_{a}$ diterima, dimana terdapat pengaruh tidak langsung kadar hemoglobin terhadap hasil belajar penjasorkes melalui kebugaran jasmani siswa putra SMA Negeri 2 Kota Padang.

Mencermati hasil uji hipotesis yang dilakukan, yaitu terdapat pengaruh tidak langsung kadar hemoglobin melalui kebugaran jasmani terhadap hasil belajar penjasorkes siswa putra SMA Negeri 2 Kota Padang. Hal ini dapat dijelaskan bahwa apabila siswa yang memiliki kadar hemoglobin yang normal, maka akan mempengaruhi kapasitas kebugaran jasmani, dalam hal ini memiliki tingkat kebugaran jasmani yang baik dan seterusnya akan mendapatkan hasil belajar penjasorkes yang baik juga.

Salah satu fungsi hemoglobin dalam darah adalah menjaga kondisi kesehatan. kadar hemoglobin normal yang akan memungkinkan seseorang cenderung memiliki ketahanan untuk berkonsentrasi dan fisik yang baik, kebugaran jasmani juga sangat menentukan keberhasilan siswa dalam mencapai hasil belajar yang maksmal, dalam pembelajaran penjasorkes siswa sangat dituntut untuk mempunyai tingkat kebugaran jasmani yang tinggi. Pencapaian hasil belajar yang maksimal melalui kadar hemoglobin yang tinggi (dalambatas normal) ditunjang oleh kebugaran jasmani yang tinggi merupakan dua factor yang saling mempengaruhi.

Hemoglobin adalah suatu protein majemuk yang mengandungm unsur non protein yaitu heme yang terdapat pada sel darah merah dan yang memberi warna merah pada darah yang berfungsi untuk mengatur pertukaran oksigen dengan karbondioksida di dalam jaringanjaringan tubuh. Kadar hemoglobin adalah kadar normal hemoglobin pada darah yang telah ditentukan oleh World Health Organization (WHO). Hemoglobin merupakan kompleks protein yang terdiri dari heme yang mengandung besi dan globin dengan interaksi diantara 
heme dan globin menyebabkan hemoglobin $(\mathrm{Hb})$ merupakan perangkat yang ireversibel untuk mengangkut oksigen (Mustaqim \& Wahyuni, 2013 : 638).

Zat besi sangat penting untuk orang yang aktif, baik pria maupun wanita. Kebanyakan zat besi yang diserap dalam darah masuk ke produksi hemoglobin, komponen sel darah merah yang membawa oksigen dari paru-paru. Zat besi juga digunakan dalam mioglobin otot untuk membawa dan menyimpan oksigen dan zat enzim oksidasi aerobik (Sharkley: 2011: 247). Berdasarkan hasil uji hipotesis yang dilakukan, hipotesis keempat HO ditolak dan Ha diterima yaitu terdapat pengaruh kadar hemoglobin melalui kebugaran jasmani terhadap hasil belajar penjasorkes siswa SMA Negeri 2 Kota Padang. Hal ini dapat dijelaskan bahwa apabila siswa yang memiliki kebugaran jasmani yang baik dan kadar hemoglobin yang normal, maka akan mempengaruhi hasil belajar penjasorkes, dalam hal ini memiliki nilai rapor baik.

\section{KESIMPULAN}

Berdasarkan hasil analisis data dan pembahasan yang telah dijelaskan pada bab sebelumnya, maka dapat diambil kesimpulan sebagai berikut:

1. Terdapat pengaruh langsung dan signifikan kadar hemoglobin terhadap hasil belajar penjasorkes siswa putra SMA Negeri 2 Kota Padang, sebesar 5.34\%.

2. Terdapat pengaruh langsung dan signifikan kebugaran jasmani terhadap hasil belajar penjasorkes siswa putra SMA Negeri 2 Kota Padang, sebesar $13.40 \%$.

3. Terdapat pengaruh tidak langsung kadar hemoglobin terhadap hasil belajar penjasorkes melalui kebugaran jasmani siswa putra SMA Negeri 2 Kota Padang, sebesar 12.9\%.

\section{DAFTAR PUSTAKA}

Agus, A. 2012. Olahraga Kebugaran Jasmani. Padang: Sukabina Press.

Arikunto, Suharsimi. (2006). Prosedur Penelitian Ilmiah Suatu Pendekatan Praktik. Jakarta: Rineka Cipta.

Chan TH.(2016) Examples of moderate and vigorous physical activity.

Chen, S. dkk. 2014. "Relationship Between Motivation and Learning in Physical Education and After-School Physical Activity". Research Quarterly for Exercise and Sport. 85, 468-477.

Chomitz, V.R., M.M. Slining, R.J. McGowan, S.E. Mitchell, G.F.nDawson, and K.A. Hacker. (2009). Is there a relationship between physical fitness and adacemic achievement? Positive results from public school children in the northeastern united states, J.Sch. Health., Vol. 79 (1), 30-37.

Dwi yanti (2017) Pengaruh Kadar Hb Terhadap Pretasi Belajar Anak Usia Sekolah Kelas II- VI di SDN Sonoageng 6 Prambon Nganjuk

Hamalik, Oemar. (2012). Proses Belajar Mengajar. Jakarta: Bumi Aksara

Hapzah: Yulita, R. 2012. Hubungan Pengetahuan dan Status Gizi terhadap Kejadian Anemia Remaja Putri Pada Siswi Kelas III di SMAN 1 Tinambung Kabupaten Polewali Mandar. Media Gizi Pangan, Vol XIII, Edisi 1

Kosasi L, Oenzil F, Yanis A. Hubungan aktivitas fisik terhadap kadar hemoglobin pada mahasiswa anggota UMK pandekar universitas andalas. Jurnal Kesehatan Andalas. 2014;3(2). 
Kurniawan, R., Rangkuti, Y. A., \& Ulfah, N. R. (2020). Hubungan Antara Fleksibilitas Pergelangan Tangan, Koordinasi Mata-Tangan, Dan Motivasi Latihan Dengan Ketepatan Pukulan Forehand Tenis Meja. Jurnal Patriot, 2(4), 951-965.

Mairbaurl H. Red blood cells in sports: effect of exercise and training on oxygen supply by red blood cells. Frontiers in Physiology. 2013;4:1-2.

(Ratey and Hagerman, 2008). Ratey,, J.J. Hagerman, E. (2008). Spark: The revolutionary new science of exercise and the brain. New York, NY: Hachette Book Group USA.

Riduwan dan Engkos Achmad Kuncoro. (2012). Cara Menggunakan dan Memakai Path Analysis (Analisis Jalur). Bandung : Alfabeta

Sadikin M. Biokimia darah. Jakarta: Widya Medika; 2002. h. 25-39.

Santoso G. Manajemen keselamatan dan kesehatan kerja. Jakarta: Prestasi Pustaka; 2004.

Sherwood, Lauralee, 2011. Fisiologi manusia dari sel kesistem, Jakarta : buku kedokteran EGC

Susanto, Ahmad. (2013). Teori Belajar dan Pembelajaran di Sekolah Dasar. Jakarta : Kencana Prenada Media Group.

Syafiq M Suheli 2017. Gambaran Kadar Hemoglobin pada Mahasiswa dengan Indeks Massa Tubuh (IMT) $\geq 23$ kg/m di Fakultas Kedokteran Universitas Sam Ratulangi

Triasih S.2005. Anemia defiesiensi besi: epidemiology and cognitive in children with iron deficiency anemia. Yogyakarta: Medika Fakultas Kedokteran UGM; 2005. 